\title{
Ulama Perempuan di Pesantren: Studi Tentang Kepemimpinan Nyai Hj. Masriyah Amva
}

\author{
Fikriyah Istiqlaliyani \\ Pascasarjana IAIN Cirebon, Indonesia \\ *Coresponding Author: fikriyahistiqlaliyani@gmail.com
}

\begin{abstract}
Islam does not limit women to be leaders, but the existence of women's leadership among Muslims is still very limited, this is due to several factors that block the potential of women's leadership, especially in Islamic educational institutions such as madrasas, pesantren and so on. However, as time goes by, many women appear who dedicate themselves to being leaders and clerics. One of them is the figure of Mrs. Nyai Hj Masriyah Amva, she is the leader of the Kebon Jambu Al-Islamy Islamic Boarding School, as well as being one of the female ulama figures in the city of Cirebon. This study aims to explain the biography of Mrs. Nyai Hj Masriyah Amva and explain data about the ideas and implementation of the leadership of Mrs. Nyai Hj Masriyah Amva at Pondok Pesantren Kebon Jambu Al-Islamy Cirebon. This research uses a qualitative research approach with the type of case study and the research model used is a literature and field study research model. The steps of this research were carried out by reviewing books, journals, previous research related to the leadership of female clerics in Islamic boarding schools as well as interviews and observations related to the figure of Mrs. Nyai Hj Masriyah Amva. The results of the study stated that Ms. Nyai Hj Masriyah Amva had a life principle of positive thinking, being optimistic (full of enthusiasm) and always learning from the experiences of herself and others. In the idea and implementation of becoming the leader of a boarding school, he succeeded in developing pesantren programs in the academic and non-academic fields. He is also a charismatic, democratic and serving leader. As a female cleric, she took part in the genderization and feminism movement.
\end{abstract}

Keywords: leadership; female clerics; boarding school.

\section{Abstrak}

Islam tidak membatasi perempuan untuk menjadi pemimpin, akan tetapi keberadaan kepemimpinan perempuan di kalangan umat Islam masih sangat terbatas, hal tersebut disebabkan karena beberapa faktor yang menyumbat potensi kepemimpinan perempuan khususnya dalam lembaga pendidikan Islam seperti madrasah, pesantren dan sebagainya. Namun seiring berjalannya waktu banyak bermunculan perempuan yang mendedikasikan dirinya menjadi pemimpin dan tokoh ulama. Salah satu diantaranya adalah sosok Ibu Nyai Hj Masriyah Amva, beliau merupakan pemimpin Pondok Pesantren Kebon Jambu Al-Islamy, serta menjadi salah satu tokoh ulama perempuan di Kota Cirebon. Penelitian ini bertujuan untuk menjelaskan biografi Ibu Nyai $\mathrm{Hj}$ Masriyah Amva dan menjelaskan data tentang gagasan dan implementasi kepemimpinan Ibu Nyai Hj Masriyah Amva di Pondok Pesantren Kebon Jambu AlIslamy Cirebon. Penelitian ini menggunakan pendekatan penelitian kualitatif dengan jenis studi kasus dan model penelitian yang digunakan ialah model penelitian kajian pustaka dan lapangan. Langkah-langkah penelitian ini dilakukan dengan cara menelaah buku-buku, jurnal, penelitian terdahulu yang berkaitan dengan kepemimpinan ulama perempuan di Pesantren serta wawancara dan observasi terkait sosok Ibu Nyai Hj Masriyah Amva. Hasil penelitian menyatakan bahwa Ibu Nyai Hj Masriyah Amva memiliki prinsip hidup berpikir positif, optimis (penuh semangat) dan senantiasa belajar dari pengalaman diri sendiri dan orang lain. Dalam gagasan dan implementasi menjadi pemimpin pondok pesantren, beliau berhasil mengembangkan program pesantren di bidang akademikdan non akademik. Beliau juga merupakan sosok pemimpin yang kharismatik, demokratis serta melayani. Sebagai tokoh ulama perempuan, beliau ikut andil dalam gerakan genderisasi dan feminisme.

Kata Kunci: kepemimpinan; ulama perempuan; pesantren. 


\section{PENDAHULUAN}

Kepemimpinan adalah suatu proses pengaruh sosial yang mana seseorang mampu memberikan bantuan dan dukungan pada yang lainnya dalam menyelesaikan tugas bersama. Kkepemimpinan sebagai proses mempengaruhi kegiatan seseorang atau kelompok dalam usaha ke arah pencapaian tujuan dalam situasi tertentu (Satrijo, 2018). Istilah kepemimpinan pada dasarnya berhubungan dengan keterampilan, kecakapan dan tingkat pengaruh yang dimiliki oleh orang yang bukan pemimpin (Masduki, 2015). Kepemimpinan merupakan tugas manajerial yang penting didalam setiap organisasi khususnya dalam pengambilan kebijakan keputusan sebagai inti dari sebuah kepemimpinan. Efektivitas kepemimpinan seseorang juga dapat ditentukan oleh kemampuannya dalam mengenali secara tepat sifat kondisi yang dihadapinya, baik kondisi yang terdapat dalam organisasi maupun kondisi yang terdapat diluar organisasi tetapi mempunyai dampak bagi jalannya organisasi yang bersangkutan (Sondang, 2015). Kepemimpinan memegang peranan sangat penting dalam pengembangan sekolah secara keseluruhan. Teori-teori dan praktik-praktik terkini dalam Pendidikan menunjukkan adanya perhatian besar pada bidang kepemimpinan (Bush \& Middlewood, 2010).

Menilik sejarah pendidikan Islam Nusantara jaman sebelum dan sesudah kemerdekaan Indonesia, peran perempuan hanya sebatas di rumah. Tidak semua perempuan berhak mendapatkan pendidikan. Paradigma masyarakat tentang perempuan hanyalah makhluk lemah yang tidak mempunyai kiprah luas dalam ranah publik di masyarakat lingkungannya. Dan masyarakat memandang perempuan hanyalah makhluk kelas dua yang tidak perlu bersekolah. Suatu hal yang tidak dapat dipungkiri adalah perempuan merupakan bagian integral dari masyarakat. Secara biologis perempuan berbeda dengan laki-laki, tetapi dari segi hak dan kewajiban sebagai manusia sama (Novianti, 2008). Jadi, keberadaan perempuan bukan sekadar pelengkap bagi laki-laki, melainkan mitra sejajar dalam berbagai aspek kehidupan, baik yang bersifat domestik seperti rumahtangga maupun publikMeskipun demikian, ajaran Islam tidak membatasi perempuan untuk menjadi pemimpin, akan tetapi keberadaan pemimpin perempuan dikalangan umat Islam jumlahnya masih sangat terbatas, hal tersebut disebabkan karena banyak faktor yang menyumbat potensi kepemimpinan perempuan dikalangan umat Islam.

Pesantren merupakan lembaga pendidikan di Indonesia yang indegenous atau asli, sehingga sejarah panjang yang melingkupinya telah menempatkan Pesantren dalam posisi take and give, sebagai penyebab dan juga akibat dalam setiap proses-proses sosial di bumi Nusantara. Secara manajerial peranan pengasuh di Pesantren menjadi semacam konstitusi dalam sistem monarki (Prasetiawan \& Lis, 2019). Dhawuh Kiai adalah perintah agung yang wajib dipatuhi secara sakral. Visi, misi, tujuan dan pemikiran seorang Kiai dapat tersurat maupun tersirat (eksplisit-implisit), sedangkan detail operasionalnya biasanya diterjemahkan dan dijalankan oleh kepengerusan santri, dari unsur santri senior (Affandi, 2012). Kiai memegang peranan sentral dalam kepemimpinan Pesantren. Sifatnya mutlak, tetapi sumber kekuasaan berasal dari sikap patuh santri dan masyarakat, sehingga membentuk kepemimpinan yang totaliter.

Pesantren pada awalnya hanya diperuntukan untuk laki-laki. Seorang santri laki-laki dipersepsikan sebagai tokoh yang akan membangun umat dan tampil di ruang-ruang publik, sedangkan perempuan dipersiapkan untuk sekedar berperan di ranah domestik yang harus dijaga ketat, misalkan menjadi seorang isteri. Sebagian besar Pesantren dipimpin oleh pengasuh seorang laki-laki. Hal ini berimplikasi terhadap manajemen pengajarannya, dimana pengajar laki-laki dapat mengajar bagi kelas santri putera dan santri puteri, tetapi tidak sebaliknya bagi pengajar perempuan. Kecuali dalam kasus yang sangat spesifik, misalnya pada bagian pelajaran tertentu, tidak ada pengajar laki laki yang kompeten, barulah pengajar perempuan dapat menjadi pengajar kelas santri laki-laki (Marhumah, 2012). Kepemimpinan Pesantren secara turun menurun menjadi haknya anak laki laki. Seorang anak perempuan meskipun memiliki kemampuan kepemimpinan tidak akan memperoleh hak kuasa pemimpin Pesantren. Perempuan dalam lingkup kuasa Pesantren menjalani semacam subordinasi. Ajaran Islam yang dikembangkan di Pesantren bersifat permanen dalam menempatkan laki-laki perempuan (Sumadi, 2017). Melihat fakta ini, potensi kepemimpinan perempuan di lingkungan Pesantren akan sangat sulit berkembang. Kepemimpinan perempuan pada pengelolaan pesantren masih menyisakan persoalan, salah satunya adalah persoalan otoritas pada diri pemimpin perempuan dalam 
lingkungan pondok pesantren. Selain faktor budaya terhadap kepemimpinan perempuan yang dinilai kurang partisipatif, otoritas seorang kyai dalam pengelolaan pesantren juga menjadi dasar munculnya persoalan itu.

Namun seiring berjalannya waktu banyak bermunculan perempuan yang mendedikasikan dirinya menjadi pemimpin pada pondok pesantren. Beberapa penelitian terdahulu telah melakukan studi terkait kepemimpinan perempuan di pondok pesantren, dianataranya penelitian yang dilakukan Maghfiroh (2019), Melamahu (2019), Muna \& Herman (2020), Nansiana et al. (2020), dan Wulpiah (2018). Penelitian ini akan berusaha memberikan deskripsi kepemimpinan salah satu ulama perempuan dan juga pimpinan salah satu pondok pesantren ternama di Cirebon. Ulama perempuan tersebut adalah Ibu Nyai Hj Masriyah Amva, beliau merupakan pemimpin Pondok Pesantren Kebon Jambu Al-Islamy, serta menjadi salah satu tokoh ulama perempuan di Kota Cirebon. Pada tahun 2017, beliau menginisiasi kegiatan Kongres Ulama Perempuan Indonesia (KUPI) yang berhasil memproduksi istilah perempuan ulama dan ulama perempuan. Perempuan ulama memuat referensi biologis sebagai semua perempuan yang memiliki kapasitas keilmuan yang otoritatif dalam bidang-bidang tertentu, sedangkan ulama perempuan adalah semuan perempuan yang memiliki otoritas keilmuan serta mampu memandang persoalan dengan perspektif keadilan hakiki dalam relasi gender (kalis, 2019).

\section{METODE PENELITIAN}

Penelitian ini menggunakan pendekatan deskriptif kualitatif, yaitu penelitian yang temuan-temuannya tidak diperoleh melalui prosedur statistik atau bentuk hitungan lainnya dan bertujuan mengungkapkan gejala secara holistik-kontekstual (Sugiarto, 2015). Strategi dan teknik penelitian yang digunakan untuk memahami masyarakat dengan sebanyak mungin mengumpulkan fakta yang mendalam, data disajikan dalam bentuk verbal, bukan dalam bentuk angka. Pendekatan kualitatif memiliki karakteristik alami sebagai sumber data langsung, deskriptif, proses lebih dipentingkan dari pada hasil, analisis dalam penelitian kualitatif cenderung dilakukan secara analisa induktif dan makna merupakan hal yang esensial (Moleong, 2013).

Jenis penelitian ini merupakan studi kasus dengan model penelitian yang digunakan penelitian kajian pustaka dan lapangan. Langkah-langkah penelitian ini dilakukan dengan cara menelaah buku-buku, jurnal, penelitian terdahulu yang berkaitan dengan kepemimpinan ulama perempuan di Pesantren serta wawancara dan observasi terkait sosok Ibu Nyai Hj Masriyah Amva. Data yang terkumpul divalidasi melalui proses triangulasi. Data yang divalidasi kemudian direduksi dan disajikan. Setelah penyajian data baru diambil simpulan.

\section{HASIL DAN PEMBAHASAN}

Ibu Nyai Hj Masriyah Amva lahir di Pesantren Babakan 13 Oktober 1961 dari pasangan KH. Amrin Hanan dan Nyai Hj Fariyatul Aini rohimahumallah. Setelah sepeningal suaminya KH. Muhammad, Ibu (Sapaan beliau) mendedikasikan dirinya menjadi pemimpin pondok melanjutkan peran suaminya. Namun dalam masa awal kepemimpinanya banyak ujian yang Ibu hadapi, seperti ketidakpercayaan para santri khususnya santri putra atas kepemimpinanya, celaan dan hinaan yang datang dari pihak luar. Meskipun demikian Ibu tetap yakin untuk melanjutkan Amanah dari alm.KH. Muhammad. Beliau percaya akan adanya pertolongan dari Allah swt, dan selalu berpegang teguh pada prinsip hidup yang dimilikinya, seperti positive thinking (berpikir positif), optimis (penuh semangat) dan senantiasa belajar dari pengalaman baik dialami sendiri atau orang lain.

Dalam menjalankan tugas dan tanggung jawabnya sebagai seorang pemimpin pondok pesantren, Ibu (sapaan beliau Nyai Hj Masriyah Amva) sangatlah memperhatikan perkembangan pondok pesantren Kebon Jambu Al-Islamy baik dari segi material maupun nonmaterial. Perannya sebagai seorang pemimpin pesantren, mampu menjadikan pondok pesantren Kebon Jambu Al-Islamy dikenal dan dipercaya oleh masyarakat umum baik dari segi akademik seperti (kurikulum yang dikembangkan di pondok, kemudian pendidikan santri dan pembelajaran kajian kitab kuning santri) dan dari segi non-akademik seperti (program peraturan pondok, kepengurusan, program ekstrakulikuler santri, kegiatan harian, kegiatan bulanan dan 
kegiatan tahunan santri baik putra maupun putri). Adapun kiprahnya sebagai tokoh ulama perempuan, Ibu Nyai Hj Masriyah Amva mendedikasikan dirinya sebagai sosok yang ikut dalam genderisasi dan memiliki faham akan feminisme serta di tahun 2017 sukses mendirikan Kongres Ulama Perempuan Indonesia (KUPI) di Pondok Pesantren Kebon Jambu Al-Islamy Cirebon.

a. Sikap Kepemimpinan Nyai Hj. Masriyah Amva Sebagai Pemimpin Pondok Pesantren Kebon Jambu AlIslamy

Nyai Hj. Masriyah Amva merupakan pemimpin yang demokratis. Pemimpin tipe ini menafasirkan kepemimpinannya sebagai pemimpin di tengah-tengah anggota kelompoknya. Hubungan dengan anggota kelompok bukan sebagai majikan terhadap buruhnya, melainkan saudara tua di antara teman-teman sekerjanya, atau sebagai kakak terhadap saudaranya. Pemimpin yang demokratis selalu berusaha menstimulasi anggota-anggotanya agar bekerja secara kooperatif untuk mencapai tujuan bersama. Pemimpin yang demokratis selalu berusaha memupuk rasa kekeluargaan dan persatuan. Ia senantiasa berusaha membangun semangat anggota kelompoknya untuk mengembangkan kinerja dan daya kreatifitasnya, selain itu juga pemimpin tipe ini memberikan kesempatan dan peluang bagi para anggotanya agar mampu mengembangkan kompetensi serta memberikan kesempatan dan kepercayaan kekuasaan untuk ditanggung jawabkan kepada bawahannya (Masduki, 2015).

Nyai Hj. Masriyah Amva merupakan Pemimpin yang kharismatik. Sikap kharismatik yang Ibu miliki adalah dimana beliau selalu mengajak dalam kebaikan dan ta'at beribadah, hal ini seperti yang dijabarkan dalam ciri-ciri pemimpin karismatik yakni pemimpin yang selalu mengajak pada kebaikan, hal ini pula senada dengan pengertian dari gaya kepemimpinan kharismatik itu sendiri yaitu pemimpin yang dikagumi oleh banyak pengikut meskipun para pengikut tersebut tidak selalu dapat menjelaskan secara konkrit mengapa pemimpin tersebut dikagumi (Sondang, 2015).Penampilan fisik ternyata bukan ukuran yang berlaku umum karena ada pemimpin yang dipandang sebagai pemimpin yang kharismatik yang kalau hanya dilihat dari penampilan fisiknya saja sebenarnya tidak atau kurang mempunyai daya tarik, usia pun tidak selalu dijadikan ukuran (Sondang, 2015).

Nyai Hj. Masriyah Amva merupakan Pemimpin yang melayani. Kepemimpinan melayani menempatkan kepentingan pengikut diatas kepentingan diri sendiri dan menekankan perkembangan pengikut, dalam arti lain bahwa kepemimpinan ini bertujuan ingin melayani kebutuhan bawahannya. Para pemimpinpelayan (servant leader) mempunyai kecenderungan lebih mengutamakan kebutuhan, kepentingan dan aspirasi orang-orang yang dipimpinnya di atas dirinya.

Dari sikap kepemimpinan yang dimiliki Ibu, kini pondok pesantren Kebon Jambu mampu berkembang dengan baik dan mampu bersaing dengan pondok pesantren lainnya dalam hal menuntut ilmu serta memperdalam agama dan potensi yang dimiliki oleh santri. Berikut beberapa program pesantren yang dikembangkan oleh Ibu meskipun telah ada sejak pondok masih dipimpin oleh alm Akang (KH Muhammad) namun program yang ada dipesantren Kebon Jambu saat ini berhasil untuk menjadikan pondok pesantren masuk dalam pesantren pilihan karena melihat output yang dihasilkan memang terbukti unggul dan berprestasi serta menjadi teladan banyak orang.

b. Kendala Ibu Nyai Hj Masriyah Amva Sebagai Pemimpin Pondok Pesantren Kebon Jambu Al-Islamy Babakan Ciwaringin Cirebon.

Perempuan diciptakan dari tulang rusuk laki-laki. Sehingga posisi perempuan berada dibawah bayangbayang laki-laki. Hal ini senada dengan pernyataan bahwa dalam masyarakat Islam, ganjalan yang terkuat seputar kemunculan pemimpin perempuan adalah ganjalan teologis (Dara \& Arafah 2017). Perempuan tidak dapat berbuat banyak seperti laki-laki, hal ini secara psikologis menjadi salah satu faktor penghambat perempuan untuk mengambil peran yang berarti dalam kehidupan bermasyarakat.

Kendala berikutnya yang dalami adalah sejarah kepemimpinan perempuan. Hal ini disebabkan karena kurangnya nama perempuan dalam sejarah dimasa lalu yang tampil sebagai pemimpin, hal ini dipakai untuk membenarkan ketidak mampuan perempuan untuk berkiprah seperti halnya laki-laki serta berada diposisi paling atas dari laki-laki. Namun tidak untuk Ibu, beliau berbeda dari perempuan lainnya, meskipun pernah 
terpuruk ketika sang suami (Akang) meninggal dunia,akan tetapi dengan tekad dan prinsip-prinsip yang dimilikinya, beliau mampu menjadi pemimpin serta mengasuh ribuan santri.

Kendala lain yang dialami adalah dalam sikap pandang yang memanggap antara tugas perempuan dan laki-laki yang pada dasarnya terkikis pada kelas masyarakat yang berpendidikan atas. Namun beda halnya dengan masyarakat yang berpendidikan rendah sebagian masih menjalankan sikap pandang tentang pembagian kerja antara laki-laki dan perempuan.

c. Upaya Nyai Hj Masriyah Amva dalam Mengatasi Kendala Sebagai Pemimpin Pondok Pesantren Kebon Jambu Al-Islamy Babakan Ciwaringin Cirebon.

Sebagaimana yang telah dijelaskan diatas, bahwasanya ketika pondok Kebon Jambu mengalami kesedihan yang mendalam, yakni sang Kyai (Akang) meninggal dunia, saat itu pula para santri yang dititipkan orangtua mereka mulai meninggalkan pesantren. Di tengah kegelisahannya beliau pun memasrahkan diri pada Tuhan, melalui tulisannya baik dalam sebuah puisi maupun dalam sebuah buku karya beliau sendiri.Salah satu puisi karya beliau yang membuktikan bahwasanya setelah musibah yang dialaminya, beliau hanya berserah diri dihadapan Allah.

Dalam hasil wawancara disebutkan bahwa, Ibu Nyai Hj Masriyah Amva merupakan sosok pribadi yang kuat, hal ini terbukti sejak beliau menggantikan peran suaminya sebagai pemimpin pondok pesantren yangsering mendapatkan sindiran bahkan menerima diskriminasi dari sejumlah kalangan termasuk ulama karena menganggap rendah sebuah lembaga pesantren dibawah oleh kepemimpinan seorang perempuan. Karena alasan seperti yang telah disebutkan diatas, maka beliau mendukung penuh bahkan menjadi bagian penuh dalam mengatasi persoalan yang dialami perempuan dan menjadikan dirinya sebagai orang yang mendukung akan genderisasi dan feminisme. Beliau mengatakan dalam sebuah wawancara mengenai genderisasi, dan beliau menjawab bahwa kita perempuan ingin setara dengan laki-laki, laki-laki bisa memimpin kenapa perempuan tidak, maka adanya genderisasi itu dengan tujuan bukan untuk merusak ataupun mengotori agama Islam,namun untuk menguatkan agama Islam dan membuat lebih maju.

Hasil dari wawancara bersama dengan salah satu pengurus dan alumni pondok dijelaskan bahwa, menurut beliau sebagai seorang pemimpin pondok pesantren Nyai $\mathrm{Hj}$ Masriyah Amva memiliki cara pandang yang luas tentang bagaimana tujuan diadakannya pendidikan Pondok Pesantren, bahwa pendidikan pondok pesantren sebagai lembaga pendidikan Agama harus bisa mencetak generasi-generasi yang islami, berahlakul karimah, beriman dan bertaqwa sebagaimana ajaran Nabi, bukan hanya itu Pondok pesantren harus bisa menanamkan nilai-nilai agama yang kuat dengan selalu mengajak santrinya untuk selalu mengingat dan hanya mengharap rahmat dan ridho Allah disetiap langkah dan tujuan. Pendidikan Pesantren juga harus bisa merubah cara pandang seseorang bahwa untuk mencapai sesuatu bukan semata-mata hanya dengan bekerja keras saja tetapi juga diimbangi dengan do'a untuk mendapat rahmat dan Ridhonya karena menurutnya dengan rahmat dan ridho Allah segala sesuatu yang kita rasakan akan lebih ringan dan berkah.

\section{KESIMPULAN}

Sikap Kepemimpinan Nyai Hj. Masriyah Amva Sebagai Pemimpin Pondok Pesantren Kebon Jambu Al-Islamy; Pemimpin yang demokratis, Pemimpin yang kharismatik, Pemimpin yang melayani. Nyai $\mathrm{Hj}$ Masriyah Amva memiliki prinsip hidup berpikir positif, optimis (penuh semangat) dan senantiasa belajar dari pengalaman diri sendiri dan orang lain. Dalam gagasan dan implementasi menjadi pemimpin pondok pesantren, beliau berhasil mengembangkan program pesantren di bidang akademikdan non akademik. Beliau juga merupakan sosok pemimpin yang kharismatik, demokratis serta melayani. Sebagai tokoh ulama perempuan, beliau ikut andil dalam gerakan genderisasi dan feminisme bahkan pesantren Kebon Jambu menjadi tuan rumah acara Kongres Ulama Perempuan Indonesia (KUPI) pada tahun 2017.

\section{DAFTAR PUSTAKA}

Affandi, F. (2012). Pola Kepemimpinan Kyai dalam Pendidikan Pesantren (Penelitian di Pondok Pesantren As-Syi'ar Leles). Jurnal Pendidikan Universitas Garut, 27. 
Dara, N., \& Arafah. (2017). Islam Kepemimpinan Perempuan Dan Seksualitas. Jakarta: Pustaka Obor.

Kalis, M. (2019). Muslimah Yang Diperdebatkan, Yogyakarta: Buku Mojok.

Maghfiroh, E. E. (2019). Kepemimpinan Pengasuh Perempuan Di Lingkungan Pesantren (Studi Atas Fenomena Kepemimpinan Nyai Maqtuatis Surroh Dalam Mengasuh Santri Putri Di Pondok Pesantren Kyai Syarifuddin Lumajang). An-Nisa', 11(2).

Marhumah, Ema. (2012). Konstruksi Sosial Gender di Pesantren: Stundi Kuasa Kiai Atas Wacana Perempuan. Yogyakarta: Lkis.

Masduki, D. (2015). Kepemimpinan Pendidikan, Jakarta: Gaung Persada Press.

Melamahu, T. H. (2019). Kepemimpinan "Bu Nyai" Dalam Pondok Pesantren Singo Wali Songo Di Kabupaten Magetan (Doctoral Dissertation, Universitas Airlangga).

Moleong, J. L. (2015). Metodologi Penelitian Kualitatif, Bandung: PT Remaja Rosdakarya.

Muna, N., \& Hamam, H. (2020). Kepemimpinan Nyai di Pesantren Al Hajar Kapurejo Pagu Kediri. Jurnal Intelektual: Jurnal Pendidikan Dan Studi Keislaman, 10(1), 46-57.

Nansiana, N., Jannah, S. R., \& Nugroho, A. D. (2020). Kepemimpinan Perempuan Dalam Mengembangkan Pondok Pesantren Diniyyah Al-Ažbar Di Muara Bungo Jambi (Doctoral dissertation, UIN Sultan Thaha Saifuddin Jambi).

Novianti, I. (2008). Dilema kepemimpinan perempuan dalam Islam. Yinyang: Jurnal Studi Islam Gender dan Anak, 3(2), 255-261.

Prasetiawan, A. Y., \& Lis, S. (2019). Kepemimpinan Perempuan dalam Pesantren. Yinyang: Jurnal Studi Islam Gender Dan Anak, 14(1), 39-69.

Satrijo, B., S. (2018). Manajemen Pendidikan, Yogyakarta: ANDI.

Sondang, P. S. (2016). Teori \& Praktek Kepemimpinan. Jakarta: Rineka Cipta.

Sumadi, S. (2017). Islam dan Seksualitas: Bias Gender dalam Humor Pesantren. El Harakah, 19(1), 21.

Wulpiah, W. (2018). Menelaah Kepemimpinan Perempuan Di Pondok Pesantren Al-Islam Kemuja. Noura: Jurnal Kajian Gender, 2(1), 1-17. 